\title{
Is Grand Strategy a Research Program? A Review Essay
}

\author{
Thierry Balzacq, Peter Dombrowski and Simon Reich
}

\begin{abstract}
The literature on grand strategy is dynamic and voluminous. Yet a vital set of questions remains unsettled. There is little agreement on such basic issues as a common definition of grand strategy, the appropriate methods that should be employed in studying it, which countries qualify as comparative cases, and whether the purpose of research is explanatory or prescriptive. This article examines four recent, important books as a platform for addressing these issues and argues that, as currently constituted, grand strategy is a field of study rather than a mature research program. It concludes by offering a modest range of options that can be employed to rectify these problems and develop a comparative grand strategy program.
\end{abstract}

What Good Is Grand Strategy? Power and Purpose in American Statecraft from Harry S. Truman to George W. Bush. By Hal Brands. Ithaca: Cornell University Press, 2015. 271 pages.

America Abroad: The United States' Global Role in the 21st Century. By Stephen Brooks and William Wohlforth. London: Oxford University Press, 2016. 288 pages.

The Evolution of Modern Grand Strategic Thought. By Lukas Milevski. London: Oxford University Press, 2016. 176 pages.

Restraint: A New Foundation for U.S. Grand Strategy. By Barry Posen. Ithaca: Cornell University Press, 2014. 234 pages.

Like nostalgia, grand strategy always seems to be fashionable. Scholars and pundits-in the United States and abroad-churn out books, articles, and editorials, parsing out every administration's foreign and security

\footnotetext{
Thierry Balzacq is the Tocqueville Chair in Security Policies and Francqui Research Chair at the University of Namur, Namur, Belgium. Peter Dombrowski is a Professor in the Strategic and Operational Research Department at the Naval War College in Newport, Rhode Island. Simon Reich is a Professor in the Division of Global Affairs and Department of Political Science at Rutgers Newark University in Newark, New Jersey. Reich spent the summer of 2018 as a visiting fellow at IRSEM in Paris, generously supported by the Gerda Henkel Foundation. Dombrowski and Reich's latest book is The End of Grand Strategy: US Maritime Operations in the 21st Century (Cornell Press, 2018). Balzacq, Dombrowski and Reich are co-editors of a forthcoming book, Comparative Grand Strategy in the Modern Age: A Framework and Cases (Oxford University Press, 2019).
} 
policies and searching for overarching patterns that indicate a higher order of thinking and coherency. ${ }^{1}$ Each crisis or policy initiative generates endless navel gazing about what it illustrates with regard to a nation's capacity for grand strategy. Close observers are often vexed by these endless debates. Some see little utility in the concept of grand strategy. In a field brimming with organizing concepts like globalization, hegemony, power transition, and securitization, critics suggest that it is unclear whether a grand strategy is necessary or even possible, much less worthy of study by scholars and analysts. ${ }^{2}$ Nonetheless, the literature on grand strategy-predominantly American grand strategy-thrives.

This paradox can partially be explained by its topicality. Every new presidential election generates debates about whether the incoming administration will have a grand strategy and, if so, what form it will take. One baffling example is a column that proclaimed that Donald Trump had no grand strategy-before he had even assumed office. ${ }^{3}$ Then, within months, scholars begin reviewing the incumbent's record to evaluate the president's performance. Presidents are continuously reviewed, and often praised or rebuked, either for their grand strategy (as was George W. Bush) or the absence of one (as was Barack Obama).

Debates therefore focus predominantly on the presence, substance, and utility of specific grand strategies. Yet more fundamental questions underlying the field of grand strategy remain unsettled. In particular, disagreements exist over three critical, often interrelated, issues: first, the definition of grand strategy and when/how it should be employed; second, how the single case study, the comparative method, or any other method can best be used to advance our knowledge of a grand strategy's processes and outcomes; and third, the costs and benefits of emphasizing prescription rather than explanation in the study and application of any grand strategy.

To illuminate these issues, we examine four major additions to the literature on grand strategy, evaluating their purpose and contemplating their contributions to what should by now be regarded as a mature research program. All are excellent books, each worthy of being read in its own right. All are engaging, well-written, and well-researched.

\footnotetext{
'Michael Clarke and Anthony Ricketts, "Did Obama have a Grand Strategy?," Journal of Strategic Studies 40, no. 1-2 (2017): 295-324.

${ }^{2}$ For a sampling of the skeptics, see Richard K. Betts, "Is Strategy an Illusion?," International Security 25, no. 2 (Fall 2000): 5-50; Colin Gray, "Why Strategy Is Difficult," Joint Force Quarterly 22 (Summer 1999): 6-12; Steven Metz, "Why Aren't Americans Better at Strategy?," Military Review 77, no. 1 (January/February 1997): 187-90; Robert Jervis, "U.S. Grand Strategy: Mission Impossible," Naval War College Review 51, no. 3 (Summer 1998): 22-36.

${ }^{3}$ Micah Zenko and Rebecca Friedman Lissner, "Trump Is Going to Regret Not Having a Grand Strategy," Foreign Policy, accessed 15 January 2017, http://foreignpolicy.com/2017/01/13/trump-is-going-to-regret-not-having-agrand-strategy/.
} 
But beyond this analysis, we use these books as an optic to reflect on the question of whether this scholarship adequately addresses the requirements of a research program, rather than simply a field. By long-standing agreement (at least according to positivist approaches), a research program should include central questions, core assumptions, and debated theories about cause-and-effect relationships, and their hypotheses should ultimately be subject to trial by evidence. ${ }^{4}$ Such a framework is presumably what Stephen Brooks and William Wohlforth mean when referring to "sound social science" (p. 10). More pointedly perhaps, as J. David Singer suggested over five decades ago, its collective purpose should be to describe, explain, and ultimately predict. ${ }^{5}$

Given these concerns, we address three questions:

- Do these works share a common understanding of grand strategy?

- Do they attempt to describe, explain, and predict, or do they detour into normative prescription?

- To what extent do they only focus on the single example of the United States and ignore the broader, comparative application of the concept to other countries, from great powers like Russia and China to smaller (albeit often pivotal) states?

\section{An Overview of the Four Texts}

Before engaging these questions, the convention regarding the structure of review articles dictates that we offer a brief overview of each of these four books, acknowledging that space limitations ensure we will fail to capture their richness or nuance. While the four differ in their purpose, they each grapple with the same set of issues raised by the contemporary study of grand strategy.

To his merit, Hal Brands is the one who most clearly acknowledges the significant impediments in thinking about and practicing grand strategy. Yet he also heralds the need for states to pursue one. What Good Is Grand

\footnotetext{
${ }^{4}$ We recognize that not all researchers in the field of security studies would subscribe to a Lakatosian approach to social science. In fact, critical security scholars would reject such a stance. Yet given that a bulk of the literature on grand strategy is committed to variants of positivism, it seems warranted to employ Lakatosian criteria. The standard text is Imre Lakatos, "Falsification and the Methodology of Scientific Research Programmes," in Criticism and the Growth of Knowledge, ed. Imre Lakatos and Alan Musgrave (Cambridge: Cambridge University Press, 1970), 91-195. For a more digestible formulation of Lakatos's argument that addresses issues central to the field of international relations, see Rudra Sil and Peter Katzenstein, Beyond Paradigms: Analytic Eclecticism in the Study of World Politics (London: Palgrave Macmillan, 2010), particularly 5-13; Colin Elman and Miriam Fendius Elman, eds., Progress in International Relations Theory: Appraising the Field (Cambridge, MA: MIT Press, 2003). For a more critical view of a Lakatosian view of international relations, see for example, Patrick Thaddeus Jackson and Daniel H. Nexon, "Paradigmatic Faults in International Relations Theory," International Studies Quarterly 53, no. 4 (December 2009): 907-930.

${ }^{5}$ J. David Singer, "The Level of Analysis Problem in International Relations," World Politics 14, no. 1 (October 1961): 77-79.
} 
Strategy? is a "work of applied history" (p. viii). Methodologically, Brands largely employs the use of a rich descriptive narrative, effectively telling a tale of how different presidential administrations, from Harry Truman to George W. Bush, "approached grand strategy" (p. viii). But that simple characterization risks understating the book's generalizable analytic and policy lesson: crafting and implementing a grand strategy is contingent as much on domestic politics as on the structural forces of international relations.

Indeed, Brands skewers some significant shibboleths in recounting the vagaries of the efforts of successive presidential administrations to formulate, garner support for, and implement a grand strategy. The Cold War, for example, is generally characterized as a bipartisan episode when the mosaic of American politics was subdued by an organizational coherence born of a single threat. By contrast, Brands examines the efforts of some of America's most distinguished and (in retrospect) beloved strategists, notably Harry Truman and Henry Kissinger. He demonstrates that they were bedeviled-and in some cases ultimately thwarted-in their efforts by a recalcitrant Congress, thereby casting the frustrations experienced by recent presidential administrations in a different light. We discover that administrations often encountered a clash between their own strategic priorities and those of Congress; different actors operated with contrasting timeframes, thus influencing decision-making; and various domestic obstacles, including the bureaucracy and the institutional structure of the political system, influence the successful enactment of a grand strategy (p. 12). Some of these findings, so simply stated, may appear commonsensical. What is remarkable, however, is the degree to which Brands's work is an antidote to much of the literature on grand strategy, particularly in his attention to domestic impediments, which are often understated in IR scholarship. ${ }^{6}$

Focusing on the ways that presidential administrations have put together the scrambled pieces of American foreign policy serves a deeper theoretical purpose. Brands aims to eliminate contradictions, confusions, and superficialities surrounding the uses of grand strategy. Thus, the four empiricallygrounded chapters which constitute the heart of the book are all organized around one overriding question, namely what is "the meaning, importance, and challenges of grand strategy" (p. vii)? Brands argues that, despite its

\footnotetext{
${ }^{6}$ Over three decades ago Richard Rosecrance and Arthur Stein called for the integration of domestic factors in the study of US grand strategy. See Richard N. Rosecrance and Arthur A. Stein, "The Study of Grand Strategy," in The Domestic Bases of Grand Strategy, ed. Richard N. Rosecrance and Arthur A. Stein (Ithaca: Cornell University Press, 1993), 11. For rare examples of work that combines domestic and external factors, see G. John Ikenberry, Liberal Leviathan: The Origins, Crisis, and Transformation of the American World Order (Princeton: Princeton University Press, 2011); Kevin Narizny, The Political Economy of Grand Strategy (Ithaca: Cornell University Press, 2007).
} 
weaknesses, grand strategy "provides statesmen with the heuristic power needed to address the day-to-day demands of global diplomacy" (p. 8). But he insists that he is not arguing in favor of restricting grand strategy to peacetime; it is also a crucial tool in preserving states' interests during wartime.

The main lesson Brands draws from his careful analysis of presidential experiences is that "there is no good alternative to grand strategy" (p. 194). Hence, Brands's prediction: "The United States will certainly need a grand strategy in the coming years" (p. 193). Unlike Brooks and Wohlforth or Barry Posen, however, Brands does not champion a specific grand strategy. Rather, he prescribes a set of "guidelines" meant to enable leaders to think about "the endeavor and the dilemmas it entails" (p. 194).

In many ways, both Brooks and Wohlforth's and Posen's books can be regarded as companion pieces in their purpose, if not their structure and content. This is no coincidence. They have been, respectively, among the primary proponents of deep engagement and restraint, an explicit debate that has come to dominate much of the recent academic and policy discourse in grand strategy studies.

Posen's argument in Restraint: A New Foundation for Grand Strategy favoring restraint as a form of retrenchment has a lineage in his work dating back nearly two decades. ${ }^{7}$ His purpose is undoubtedly prescriptive, to convince the reader-and possibly the policy community-that America should abandon the pursuit of what he terms a liberal hegemonic grand strategy. Posen argues that this strategy, composed of equal parts primacy and cooperative security, has proven costly and ineffective (p. 6-7). The United States incurs unjustifiable costs because of free riders (such as NATO members and Japan) who benefit from its protection (p. 35-37) and risks being drawn into unnecessary conflicts by reckless drivers (Israel being his prime example) with whose fate the United States is inextricably tied, whether through a succession of legal agreements or affection (p. 45-48).

Instead, Posen advocates that the United States pursue a grand strategy of restraint (p. 69-71) that fuses elements of selective engagement and isolationism (p. 7). Recalling-and recasting for the contemporary era-a perspective famously employed by American naval officer Alfred Thayer

\footnotetext{
${ }^{7}$ See, as examples, Barry R. Posen and Andrew L. Ross, "Competing Visions for U.S. Grand Strategy," International Security 21, no. 3 (Winter 1996/97): 5-53; Barry R. Posen, "Command of the Commons: The Military Foundation of American Hegemony," International Security 28, no. 1 (Summer 2003): 5-46; Barry R. Posen, "The Case for Restraint: America Has Been Trying to Do Too Much with Too Little. It's Time to Do Less and Succeed More," American Interest, 1 November 2007, http://www.the-american-interest.com/articles/2007/11/01/the-case-forrestraint/; Barry R. Posen, "Pull Back," Foreign Affairs, 1 January 2013, http://www.foreignaffairs.com/articles/ 138466/barry-r-posen/pull-back; Barry R. Posen, "The Case for Doing Nothing in Iraq," Politico, 16 June 2014, accessed 18 August 2017, http://www.politico.com/magazine/story/2014/06/the-case-for-doing-nothing-in-iraq107913.html\#.U6rCkqjGP9c.
} 
Mahan at the end of the nineteenth century, Posen endorses a focus on the control of access to air, sea, and space: a "Command of the Commons," (p. 136; 140-43), notably a sea-based strategy (p. 163).

This formulation extends to a regional analysis that examines both the character and extent of the threat to US interests (which in most cases is, he suggests, significantly overstated), the costs of liberal hegemony, and the benefits of restraint. Posen offers a comprehensive analysis and a command of the data on military strategy and resources. It is only occasionally marred by the awkwardness any avowed realist analysis (p. 23) often encounters when wrestling with the problem of addressing the challenge posed by nonstate, nonterritorial actors-notably, in this case, al-Qaeda (see, for example, p. 86-87). Furthermore, despite the occasional nod to the role of economic resources as an instrument of national power (see, for example, p. 17), he overly focuses on the proposed military strategy (and force posture or structure) required to achieve a Command of the Commons. The great strength of his knowledge of the latter paradoxically highlights the limitations in his knowledge of the former, beyond the immediate question of the size of defense budgets. Finally, in contrast to Brands, Posen pays great attention to domestic debates but relatively little attention to the domestic political processes involved in the adjudication, formulation, and implementation of grand strategy.

Posen's book was published in 2014, but readers will notice how some elements of his position have now come to prominence and indeed been adopted by the incumbent Trump administration, despite Posen's criticism of it. ${ }^{8}$ These elements include a greater focus on burden-sharing (with Asian and European allies), great power competition (against China and Russia), sustaining a freedom of the seas (for example, in the South China Sea) and enhancing American naval capabilities (although Posen is critical of the utility of aircraft carriers). In an interview prior to Trump's inauguration, Posen clearly rejects some key aspects of the Trump administration's behavior as being inconsistent with a restraint strategy. These include its occasional use of a primacist strategy (for example, in dealing with North Korea), broad continued engagement in numerous irregular wars against terrorist organizations (in places like Afghanistan), and the growth of the Army rather than its shrinkage, as Posen advocates (p. 163). ${ }^{9}$ Nonetheless,

\footnotetext{
${ }^{8}$ Barry R. Posen, "The Rise of Illiberal Hegemony: Trump's Surprising Grand Strategy," Foreign Affairs (March/April 2018), https://www.foreignaffairs.com/articles/2018-02-13/rise-illiberal-hegemony.

${ }^{9}$ Mina Pollman, "A Discussion on Grand Strategy and International Order with Barry Posen," Center for International Maritime Security blog, accessed 3 January 2017, http://cimsec.org/barry-posen-draft/30281. For a more extensive discussion of the characteristics of these operations during the Trump administration, see Peter Dombrowski and Simon Reich, "Does Donald Trump Have a Grand Strategy?," International Affairs 93, no. 5 (September 2017): 1013-37; Peter Dombrowski and Simon Reich, "Beyond the Tweets: President Trump's Continuity in Military Operations," Strategic Studies Quarterly 12, no. 2 (Summer 2018): 56-81.
} 
elements of Posen's prescription may have garnered the attention of those in Washington.

Brooks and Wohlforth purposively spar with Posen. An early formulation of their argument was their renowned piece, "Don't Come Home, America," co-authored with G. John Ikenberry. ${ }^{10}$ Explicitly challenging Posen's restraint argument, it offered a cost-benefit analysis, prescriptively defending the utility of the (then) conventional, largely uncontested strategy of deep engagement and calling for its renewal. Brooks and Wohlforth sustain and develop that position in their book (p. 9), arguing that in providing "the most comprehensive assessment of US Grand Strategy's grounding in theory and evidence yet attempted, we demonstrate that a foundational policy pillar-a globally engaged America-remains the wisest choice" (p. 11-12). Evolving their position from the original article, they focus more on how their prescription serves a narrow definition of American economic and security interests by distinguishing between deep engagement-entailing a focus on a sustained global military presence and institution building-and deep engagement plus which also includes "democracy promotion, fostering human rights, humanitarian interventions, and the spread of other liberal values" (p. 73). In contrast to Posen's deep regionby-region analysis, Brooks and Wohlforth largely rely on aggregate data, embarking on a series of chapters that examine the costs and benefits of America's current global economic and security engagement. Unsurprisingly, they repeatedly conclude that a retrenchment strategy overstates the costs and understates the benefits of America's current grand strategy (see p. 134). But notably, they spend little time relating the data they copiously assemble to the question of how that data is linked to any specific American grand strategy in terms of cause and effect. Deep engagement, for example, implies economic integration, and the data they present evaluates the costs and benefits of such integration. Critics might argue that their work is more an examination of liberal propositions than it is about the relationship between grand strategy and economic development, technological innovation, or the forward deployment of military forces.

Milevski's The Evolution of Grand Strategic Thought is the most abstract and deductive of the four volumes. It explains the differences in the understanding of grand strategy that underpin the three previously discussed books. Further, he interprets disagreements over policy prescriptions that pit Posen against Brooks and Wohlforth as the manifestation of a longstanding competition among different formulations of grand strategy. Milevski argues that differences in the underlying assumptions scholars make about grand strategy conceal (as well as reveal) a poor understanding

\footnotetext{
${ }^{10}$ Stephen G. Brooks, G. John Ikenberry, and William C. Wohlforth, “Don't Come Home, America: The Case Against Retrenchment," International Security 37, no. 3 (2012-13): 7-51.
} 
of the history of grand strategic thought. The purpose of his book is therefore to describe its evolution, focusing on the United Kingdom and the United States to demonstrate that disagreements over what grand strategy means and its implementation entails derive from the fact that scholars dwell upon different, often competing, intellectual traditions (p. 148). Highlighting this point, he discusses the works of several formative figures in grand strategy, including Alfred Mahan, Julien Corbett, J. F. C. Fuller, B. H. Liddell Hart, and Edward Meade Earle. While the inclusion of such a large number of thinkers in one condensed book does insufficient justice to any of them, its main virtue is to illustrate how the meaning of the term altered as it was embedded in successively wider waves of political and military debate.

While the coexistence of different traditions can favor diversity, Milevski argues that it has led to vastly contrasting conceptions of grand strategy, with detrimental effects on communication and mutual understanding (p. 143). Importantly, a recurrent lack of conceptual rigor marginalizes a "critical engagement with the theoretical function of grand strategy" (p. 141). As a consequence, grand strategy remains a "standardless, incoherent concept" (p. 141), which collapses analysis and prescription. But in conceiving of grand strategy as a means of prescribing effective policy, "few authors sought to address the concept of grand strategy theoretically but preferred instead its non-rigorous employment to prescribe courses of action or to examine the course of historical events holistically" (p. 127). For Milevski, this lack of rigor is detrimental to the overall endeavor of thinking about and practicing grand strategy, as "an unclear mass of somewhat incommunicable ideas stands a lower chance of exerting influence" (p. 7).

What, then, should be done? Milevski proposes two avenues for improving our understanding of grand strategy. The first is to appreciate the contextual character of any definition (p. 7, 144, 148). Reminiscent of Quentin Skinner's historical contextualism, Milevski observes that its shifting meaning reflects the circumstances that prevail at the time of writing. ${ }^{11}$ Strategic contingencies, the goals of policymakers, and even an author's personal background have a profound bearing upon the definition of grand strategy. In this light, there are major barriers-and potentially even an inherent risk-in utilizing a definition of grand strategy in differing contexts. The challenging task is therefore to carve out a formulation that is neither problem-specific nor context-bound.

The second avenue Milevski proposes to proposes to buttress is the concept's relevance - to shepherd a contemporary "rehabilitation of grand strategy" in order to "universaliz[e]" its understanding (p. 139). While

\footnotetext{
${ }^{11}$ On Quentin Skinner's contextualism, see James Tully, Meaning and Context: Quentin Skinner and his Critics (Cambridge: Cambridge University Press, 1988).
} 
offering an intellectual history, Milevski is-perhaps paradoxically-critical of other historical approaches. He suggests that "such usages of grand strategy by historians rarely contribute towards the theoretical debates on what grand strategy is" (p. 133). Ultimately, he believes that the aim of this research should be to produce scholarship that is not case-specific but rather cumulative.

Having briefly summarized the essence of these four books, we now turn to how they address the three questions outlined in our introductory section.

\section{The Meaning and Application of Grand Strategy}

It is hard to overstate how much questions of definition bedevil contemporary studies of grand strategy. ${ }^{12}$ Minimally, grand strategy links explicit values to "ends, ways, and means." ${ }^{13}$ But to echo Milevski's admonition, there is a substantial spectrum within that broad parameter. Writing in 1941, B. H. Liddell Hart-a doyen of the concept-wrote:

Grand strategy should both calculate and develop the economic resources and manpower of nations in order to sustain the fighting services. Also the moral resources-for to foster the people's willing spirit is often as important as to possess the more concrete forms of power. Grand strategy, too, should regulate the distribution of power between the several services, and between the services and industry. Moreover, fighting power is but one of the instruments of grand strategy-which should take account of and apply the power of financial pressure, of diplomatic pressure, of commercial pressure, and, not the least of ethical pressure, to weaken the opponent's will. ${ }^{14}$

This comprehensive characterization has largely been discarded by contemporary scholars, although Liddell Hart's further musings on the need for grand

\footnotetext{
${ }^{12}$ Most studies implicitly or explicitly subscribe to varied definitions of grand strategy, whether novel or appropriated from elsewhere. For a mere sample of discussions of the term over the last four decades, see John M. Collins, Grand Strategy: Principles and Practices (Annapolis: Naval Institute Press, 1973); Barry R. Posen, The Sources of Military Doctrines: France, Britain, and Germany between the World Wars (Ithaca: Cornell University Press, 1984); Paul Kennedy, "Grand Strategy in War and Peace: Toward a Broader Definition," in Grand Strategy in War and Peace, ed. Paul Kennedy (New Haven: Yale University Press, 1991), 1-7; Williamson Murray and Mark Grimsey, "Introduction: On Strategy," in The Making of Strategy: Rulers, States, and War, ed. Alvin H. Bernstein, MacGregor Knox, and Williamson Murray (New York: Cambridge University Press, 1994), 1-2; Robert Art, A Grand Strategy for America (Ithaca: Cornell University Press, 2003); Avery Goldstein, Rising to the Challenge: China's Grand Strategy and International Security (Stanford: Stanford University Press, 2005); Christopher Layne, The Peace of Illusions: American Grand Strategy from 1940 to the Present (Ithaca: Cornell University Press, 2006); Colin Dueck, Reluctant Crusaders: Power, Culture, and Change in American Grand Strategy (Princeton: Princeton University Press, 2006); John Lewis Gaddis, "What Is Grand Strategy?," (keynote address at the "American Grand Strategy After War" conference sponsored by the Triangle Institute for Security Studies and the Duke University Program on American Grand Strategy, Chapel Hill, North Carolina, February 26, 2009); Edward Luttwak, The Grand Strategy of the Byzantine Empire (Cambridge, MA: Cambridge University Press, 2009); Colin Gray, The Strategy Bridge: Theory for Practice (Oxford: Oxford University Press, 2010); Stephen Krasner, "An Orienting Principle for Foreign Policy: The Deficiencies of 'Grand Strategy'," Policy Review no. 163 (October/November 2010): 5; William C. Martel, Grand Strategy in Theory and Practice: The Need for An Effective American Foreign Policy (New York: Cambridge University Press, 2015).

${ }^{13} \mathrm{Not}$ all scholars are enamored with this classic formulation. Jeffrey W. Meiser, "Ends + Ways + Means $=(B a d)$ Strategy," Parameters 46, no. 4 (Winter 2016-17): 81-91.

${ }^{14}$ Basil Henry Liddell Hart, Strategy, $2^{\text {nd }}$ ed. (London: Faber \& Faber, 1967), 322.
} 
strategy to include a counter-insurgency element, nation-building after warfare, and winning the peace suggests its continued relevance. But despite rejecting his formulation, contemporary scholars do not agree on a single alternative.

Indeed, Milevski discerns a lack of coherence in grand strategy's meaning, which he attributes to its "popular and widespread use and misuse" (p. 127). Brooks and Wohlforth and Posen illustrate this point in their differing definitions of grand strategy, both of which reject Liddell Hart's formulation. Posen, for example, suggests that:

A grand strategy is a nation-state's theory about how to produce security for itself. Grand strategy focuses on military threats, because these are the most dangerous, and military remedies because these are the most costly. Security has traditionally encompassed the preservation of sovereignty, safety, territorial integrity, and power position-the last being the necessary means to the first three... . A grand strategy contains explanations for why threats enjoy a certain priority, and why and how the remedies proposed could work. A grand strategy is not a rulebook; it is a set of concepts and arguments that need to be revised regularly (p. 1).

Brooks and Wohlforth, more economically, suggest that "grand strategy is a set of ideas for deploying a nation's resources to achieve its interests over the long run" (p. 75). Nonetheless, their formulation is effectively broader than Posen's because it evaluates economic opportunities as well as military threats (p. 3).

Brands, while recognizing that grand strategy "defies any singular definition," offers yet another: "I define grand strategy as the intellectual architecture that gives form and structure to foreign policy" (p. 3). Milevski, one of the few scholars to delve deep into the evolving character of grand strategy, laments that the term is consistently used in promiscuous ways (p. 1, $25,104,127)$. Yet at no point does he clarify the meaning he confers to the term or synthesize existing ones. As a result, these varied definitions do not culminate into an integrated conceptual apparatus.

The problem may have less to do with the presence of many definitions of the same phenomenon than with the coexistence of definitions that refer to completely different activities and, hence, whose analytical merits are difficult to evaluate. ${ }^{15}$ Some authors focus exclusively on traditional military threats; others also include economic dimensions; and policymakers and official strategy documents often extend the analysis to nontraditional threats such as climate change, pandemics, and economic security. ${ }^{16}$

There are two related, problematic features of the literature on grand strategy as a result. First, those employing the term cannot resolve the question of what does and does not constitute a grand strategy. In the

\footnotetext{
${ }^{15}$ See Hew Strachan, The Direction of War: Contemporary Strategy in Historical Perspective (Cambridge: Cambridge University Press, 2013).

${ }^{16}$ See, for example, National Security Strategy of the United States 2015, February 2015 (Washington, DC: The White House, 2015), accessed 15 March 2015, https://www.whitehouse.gov/sites/default/files/docs/2015 _ national_security_strategy.pdf.
} 
absence of conceptual rigor about its definition, grand strategy therefore trammels rather than facilitates communication and understanding among scholars (and indeed policymakers). Arising from this first point, the second-and perhaps most enduring aspect-is that there is an explicit contest between narrow and broad accounts of grand strategy.

In fact, as we describe below, scholarship tends to coalesce around two traditions: the classicist and the international relations traditions of grand strategy. Both approaches do generally adopt a historical analysis to justify their claims. But they often run in parallel silos differing on two main axes: the logic of grand strategy, on the one hand, and the substance of grand strategy, on the other. Neither school is internally homogenous; proponents of each are acquainted with the constitutive elements of both. Furthermore, scholars associated with the classicist tradition like Posen acknowledge that grand strategy addresses the widest range of a nation's interests (p. 2). In contrast to the international relations tradition, however, they concentrate primarily on how "the military instrument should be employed to realize them." 17 The following section explores some of the major developments in the definition and purpose of grand strategy that have been used by the books under review.

\section{The Classicist Tradition of Grand Strategy}

In Restraint, Posen develops a conception of grand strategy that emphasizes the use of military capabilities to achieve a nation's security. The grand strategy of restraint is supported by a military strategy-Command of the Commons-and a distinct force structure (p. 135). For Posen, grand strategy's core purpose is to address "direct, imminent, and plausible military threats by other nation-states" (p. 3). War (or, less dramatically, conflict) structures the logic of grand strategy. In Posen's words: "Grand strategy is ultimately about fighting" (p. 1). In his defense of the argument that grand strategy concentrates on national securitynarrowly conceived as sovereignty, territorial integrity, power position, and safety-Posen refers to it as a "key component of a state's overall foreign policy" (p. 2). Brands largely concurs with Posen on this point, and he examines the relationship between grand strategy and foreign policy. But in contrast to Brands, Posen clearly distinguishes between the two, noting that foreign policy entails the pursuit of goals unrelated to grand strategy: one does not subsume the other. ${ }^{18}$

Posen thus returns us to a nineteenth century conception of grand strategy; reading Milevski's The Evolution of Modern Grand Strategic Thought enables us to periodize Posen's classicist view. Synthesizing definitions of

\footnotetext{
${ }^{17}$ Robert J. Art, A Grand Strategy for America (Ithaca: Cornell University Press, 2004), 10.

${ }^{18}$ In this understanding, grand strategy and foreign policy do not differ in the goals pursued, but in the kind of instruments employed to reach them. This approach comes closest to John Hattendorf's, England in the War of the Spanish Succession: A Study of the English View and Conduct of Grand Strategy, 1702-1712 (New York: Garland Publishing, 1987). However, when scholars insist on both the military means and on military threats, they tend to regard grand strategy as a "key component of a state's overall foreign policy," which is necessarily broader. This is Posen's view (p. 3). But others hold that "grand strategy . . . is broader than foreign policy," an example being Braz Baracuhy, "The Art of Grand Strategy," Survival 53, no. 1 (2011): 151.
} 
grand strategy at that time, Milevski argues that during the nineteenth century, "grand strategy was fundamentally a military concept" (p. 25). Brooks and Wohlforth criticize this approach-of focusing on the military and winning wars-for being "based on a profoundly biased view of power in international politics. For power is every bit as much about the ability to prevent unfavorable outcomes as it is about the ability to cause favorable ones" (p. 12). But perhaps more problematically, while this understanding of grand strategy clearly specifies its logic (war and preparations for war) and its substance (military capabilities and how they are employed during wars), it differs little from what is characterized as within the rubric of contemporary military strategy. Importantly, moreover, an exclusive focus on military force appears inconsistent with the contemporary environment of world politics-a point reinforced by academics, policymakers, and the military itself. ${ }^{19}$

This trend away from a classicist focus accords with the findings of a growing swathe of scholarship on the forms and significance of strategic influence. ${ }^{20}$ Unlike Posen, that literature does not assess military costs in isolation. Rather it compares how well military capabilities fare vis-à-vis other, nonmaterial sources of power. A noteworthy example of this kind of work is Joseph Nye's Soft Power: The Means to Success in World Politics. ${ }^{21}$ According to Nye, a nation's power can no longer (if it ever could) rest solely on its military or even economic might, often referred to as the "hard" dimensions of power. ${ }^{22}$ The recipe for success in world politics is therefore to configure "hard" and "soft" power into "smart power." 23 It is, however, difficult to demonstrate the analytical dividends of soft power, because ways to measure its consequences remain elusive. ${ }^{24}$ Yet the fact that states invest a large amount of resources into deploying diplomatic networks and fashioning institutions congenial to their interests or that defend their way of life indicates that they employ means other than military capabilities to shape the nature of strategic outcomes. ${ }^{25}$ To some extent, this is what both Brooks and Wohlforth and Brands assume, although the boundaries between grand strategy and foreign policy are

\footnotetext{
${ }^{19}$ For respective examples, see Terry Deibel, Foreign Affairs Strategy: Logic for American Statecraft (New York: Cambridge University Press, 2007), 4-6; National Security Strategy, February 2015; and Charles Timothy Hagel, 2014 Climate Change: Adaptation Roadmap (Washington, DC: Department of Defense, 2014). Even the Trump Administration's 2017 National Security Strategy-commonly characterized as a return to a more conventional, state-based approach-lists immigration, illicit drugs, unfair trade practices, and job insecurity among the major threats facing the United States. See National Security Strategy of the United States of America, December 2017 (Washington, DC: The White House, 2017), accessed 3 January 2018, https://www.whitehouse.gov/wpcontent/uploads/2017/12/NSS-Final-12-18-2017-0905.pdf, p. 1.

${ }^{20}$ See Paul Gordon Lauren and Gordon A. Craig, Force and Statecraft: Diplomatic Challenges of Our Time (Oxford: Oxford University Press, 2013); David A. Baldwin, Economic Statecraft (Princeton: Princeton University Press, 1985).

${ }^{21}$ Joseph S. Nye, Soft Power: The Means to Success in World Politics (New York: Public Affairs, 2004).

${ }^{22} \mathrm{lbid}$. For a study that showcases the long-standing relevance of material and nonmaterial (also called ideational) factors in grand strategy, see Williamson Murray, "Thoughts on Grand Strategy," in The Shaping of Grand Strategy: Policy, Diplomacy, and War, ed. Williamson Murray, Richard Hart Sinnreich, James Lacey (New York: Cambridge University Press, 2011), 1-33.

${ }^{23}$ See Joseph S. Nye, The Future of Power (New York: Public Affairs, 2011), 177-86.

${ }^{24}$ Simon Reich and Richard Ned Lebow, Good-bye Hegemony! Power and Influence in the Global System (Princeton: Princeton University Press, 2014), 33-34.

${ }^{25}$ Martel, Grand Strategy, 17.
} 
blurred in Brands's book, making it challenging to trace the distinctive weight of each constitutive segment of power on a state's grand strategy.

From Posen's perspective, efforts such as those of Brooks and Wohlforth to explore nonmilitary bases of grand strategy are problematic. To Posen, these views "dilute the most important purpose of grand strategy, which is to address the fact that the state exists in a world where war is possible" (p. 2); furthermore, he believes "a grand strategy enumerates and prioritizes threats, and potential political and military remedies to threats" (p. 1). ${ }^{26}$ Indeed, he suggests, the aim of grand strategy is to subject "military power ... to the discipline of political science" (p. xii).

Likewise, Milevski frets at attempts to meld grand strategy with foreign policy assumptions, as he believes that doing so risks depriving grand strategy of both its autonomy and coherence as a distinct area of study. In this context, Colin S. Gray's proposal for redeeming the core of grand strategy may be useful. ${ }^{27} \mathrm{He}$ encourages strategic studies to reclaim the concept of grand strategy in order to deflect what he views as the menace of demilitarization that stems from the normative commitments of some members of the security studies community. In this respect, grand strategy plays a mediating role between security studies and strategic studies. ${ }^{28}$

Yet this idea runs up against two prospective problems, dependent on whether scholars endorse a narrow or broader approach to security studies. ${ }^{29}$ First, Gray reopens but does not resolve the debate that has split security studies into two camps since the 1990s: those who endorse a narrower, military conception of the field and those who advocate the extension of security studies to other issue areas, including economics, the environment, and a host of emergent nontraditional security issues. How can grand strategy be a credible middle ground if its core duplicates-rather than merely overlaps-that of other areas of strategy?

Second, while the military dimension is only one among several, the prospect of settling on a compromise position seems remote because there are three elements to integrate: strategy, nonmilitary sectors of security, and

\footnotetext{
${ }^{26}$ Martel disagrees: "Grand strategy," he argues, "is not and never has been simply about war or the conduct of war-in fact, war often represents a failure of grand strategy." Martel, Grand Strategy, 4. Compare this rebuttal with Milevski, who takes a somewhat more nuanced approach to the relationship between war and grand strategy (p. 15-26).

${ }^{27}$ Colin S. Gray, "Approaching the Study of Strategy," in International Security and War: Politics and Grand Strategy in the 21st Century, ed. Ralph Rotte and Christoph Schwartz (New York: Nova, 2011), 17. Sketched in Milevski (p. 152).

${ }^{28}$ David A. Baldwin, "Security Studies and the End of the Cold War," World Politics 48, no. 1 (October 1995): 117-41; Richard K. Betts "Should Strategic Studies Survive?," World Politics 50, no. 1 (October 1997): 7-33.

${ }^{29}$ For a recent presentation of this debate, see Philippe Bourbeau, Thierry Balzacq, and Myriam Dunn Cavelty, "International Relations: Celebrating Eclectic Dynamism in Security Studies," in Security: Dialogue Across Discipline, ed. Philippe Bourbeau (Cambridge: Cambridge University Press, 2015), 111-36. Earlier contributions attempting to delineate the parameters of security studies and strategic studies include, most prominently, Stephen M. Walt, "The Renaissance of Security Studies," International Studies Quarterly 31, no. 2 (June 1991): 211-39; David A. Baldwin, "The Concept of Security," Review of International Studies 23, no. 1 (January 1997): 5-26; Betts, "Should Strategic Studies Survive?"
} 
grand strategy. As a result, although Milevski detects a potential benefit in Gray's middle way, he regrets that it "remains as riddled with unspecified assumptions as all the other interpretations of grand strategy" (p. 152). In order to revamp the analytical clout of grand strategy, Milevski therefore advocates a program of "rehabilitation," attempting to "ensure the intellectual and practical relevance" of grand strategy, mainly through conceptual clarification and theoretical growth (p. 152-53).

Milevski's proposed course of action involves a two-step process. The first develops an integrated account of strategy, which integrates military and nonmilitary instruments into a single strategy. The second rehabilitates the concept of grand strategy to promote a "more mature understanding of strategy, politics, and policy ..." (p. 152). Yet what constitutes a "mature understanding" is unspecified, leaving grand strategy with a quandary. On the one hand, he calls for a genuine connection between military and nonmilitary instruments in ways that preserve their respective character. On the other, the prospect of any rehabilitation encourages efforts to explicitly locate grand strategy-both its formulation and its implementationwhere strategy, politics, and policy intersect.

Milevski, however, never elaborates on how his rehabilitative program might be implemented to improve research and practice. Indeed, because he concludes his account of the evolution of grand strategy before much of the most recent wave of research appeared, at least some of this transformation may have already taken place. ${ }^{30}$ Unfortunately, his otherwise useful intellectual history still leaves the concept in disarray. As he plaintively confesses: "Within the terra incognita on the conceptual map of strategic studies and its disciplinary environs may-or may not-reside a definitive place for grand strategy" (p. 153).

\section{The International Relations Tradition of Grand Strategy}

In contrast to Posen's classicist approach, those who favor broadening the concept end up (perhaps inevitably) pulling the term in divergent directions: temporally and substantively. Brands's What Good Is Grand Strategy? puts it at the service of wider foreign policy goals. Brooks and Wohlforth share Brands's broader scope but not his timeframe: while Brands sees grand strategy as mediating "between short-term actions and medium- and long-term goals" (p. 4), Brooks and Wohlforth treat grand strategy as "strategy conceived on the longest scale of time and comprehensiveness" (p. 80). Further, they explicitly focus on forthcoming developments; they evaluate how grand strategic options will serve both US interests and the

\footnotetext{
${ }^{30}$ Interestingly, Milevsky's bibliography includes the Brands volume discussed here but neither Posen's nor Brooks and Wohlforth's book.
} 
current world order far into the future, as rivals like China continue to grow and perhaps challenge the existing American-led system.

Thus from this perspective, strategy is submerged into grand strategy, inverting its nineteenth century usage. ${ }^{31}$ Grand strategy is seen as a metastrategy; grand strategy and strategy are simply temporally differentiated according to whether the key realm of intervention is now or in the future. ${ }^{32}$ This, however, leaves unresolved the critical issue of whether the division of tasks between grand strategy and strategy also exists along temporal lines. In Brands's version, it certainly shapes state's action in the present (p. 206). In Brooks and Wohlforth's work, however, grand strategy is more enduring than strategy. ${ }^{33}$

Nonetheless, despite these disagreements, an alternative international relations tradition of grand strategy has emerged. While its proponents recognize the role of military capabilities, they assume that "grand strategy controls military strategy, which is one of its elements." 34 As Brands argues, grand strategy is the "highest form of statecraft" (p. 1). But military force is just one of a constellation of different kinds of instruments. Furthermore, this perspective pays a greater attention to societal, economic, and technological dimensions, seeking to correct an asymmetry between ends and means, which it contends characterizes other approaches to grand strategy. An array of responses and instruments corresponds to the diversity of interests and threats. The pursuit of security is therefore explicitly subject to the effective marshaling of a host of factors that grand strategy is meant to rank, balance, and coordinate to avoid (in the case of the United States) the realization of a threat or decline. Brooks and Wohlforth, for example, embark on this task by drawing upon a definite set of theories-assurance, deterrence, leverage, and cooperation (p. 94-102).

Indeed, both Brands's and Brooks and Wohlforth's books embrace a holistic understanding of grand strategy. According to Brands, "A grand strategy represents an integrated scheme of interests, threats, resources and policies" (p. 3). Likewise, in America Abroad, Brooks and Wohlforth undertake an extensive analysis of both the foundations and operation of their preferred option of deep engagement through a framework that interweaves security, economics, technology, and institutional elements.

In fact, Brooks and Wohlforth take inspiration from Brands's understanding of the relationship between grand strategy and foreign policy

\footnotetext{
${ }^{31}$ See Charles James, A New and Enlarged Military Dictionary, or, Alphabetical Explanation of Technical Terms (London: The Military Library, 1805).

${ }^{32}$ For a succinct argument in favor of grand strategy as meta-strategy, see Alisdair Roberts, "Grand Strategy is Not Grand Enough," Foreign Policy, accessed 20 February 2018, https://foreignpolicy.com/2018/02/20/grandstrategy-isnt-grand-enough/.

${ }^{33}$ This presupposes, argues Sinnreich, that the environment itself remains unaltered. Richard Hart Sinnreich, "Patterns of Grand Strategy," in Shaping of Grand Strategy, 254.

${ }^{34}$ Collins, Grand Strategy, 15.
} 
(p. 80); Brands contends that "grand strategy (is) the intellectual architecture that gives form and structure to foreign policy-and thus its military policy, its diplomacy, and other subsidiary components of foreign policy" (p. 3-4). Likewise, Brooks and Wohlforth argue that grand strategy "provides a blueprint or guiding logic for a nation's policies across many areas" (p. 75). Furthermore, in reinforcing Brands's "conceptual center of gravity" (p. 8), they quote John Lewis Gaddis in calling attention to "the process by which a state relates long-term strategic ends to means under the rubric of an overarching and enduring vision to advance the national interest" (p. 78). ${ }^{35}$ In contrast to Posen, the scope is therefore broader and the timeframe longer.

This alternative conception of grand strategy is linked to three characteristic features of at least one strand of international relations. The first is the linkage between grand strategy and the rational prioritization of objectives. The second is the adjustment of limited resources to serve those objectives. The third is a focus on process, not simply structure: grand strategy requires the identification of an intellectual framework, preferably an overarching concept, which anchors a nation's foreign policy. In short, Brands argues that "grand strategy is as much a process as it is a single principle" (p. 4). We examine each of these features in turn.

What kind of process is grand strategy? While neither Brands nor Brooks and Wohlforth clearly address the issue, their books contain a rich array of clues from which an answer might be derived. Grand strategy is strategic precisely because, says Brands, "any competent grand strategist will try to shape his country's interactions in the most advantageous way possible, but his choices will unavoidably be affected by the fact the adversaries as well as allies are trying to do exactly the same thing" (p. 5). ${ }^{36}$ In these circumstances, it is a "discipline of trade-offs" and "ruthless prioritization" in the provision of the most effective edge against vital threats to a country's national interests (p. 4). According to Gaddis, the relationship between means and ends is "deliberate," not "accidental, inadvertent or fortuitous;" it is "calculated." 37 This interpretation is useful because it buttresses the growing consensus around the nature of the relationship between grand strategy and policy: policy springs from, and is shaped by, grand strategy.

Milevski, however, takes a dim view of policy being subservient to grand strategy. For him, grand strategy and policy serve different roles: the former provides overall direction to-and limits the states' initiatives in pursuit oflong-term objectives; the latter performs "the relational step to fulfill those goals with available means" (p. 141). Yet if this is the case, it reverses the

\footnotetext{
${ }^{35}$ The quote comes from Gaddis, "What Is Grand Strategy?," 7.

${ }^{36}$ This interactive aspect of grand strategy is similar to Walter A. McDougall, "Can the United States Do Grand Strategy?," Orbis 54, no. 2 (2010): 165-84.

${ }^{37}$ John Lewis Gaddis, "Containment and the Logic of Strategy," The National Interest, no. 10 (Winter 1987/8): 19.
} 
hierarchical relationship between policy and grand strategy, rather than denying a relationship between the two. To Milevski, policy becomes the raison d'être of grand strategy. This approach resembles that of Paul Kennedy. "The crux of grand strategy," according to Kennedy, "lies ... in policy, that is, in the capacity of the nation's leaders to bring together all the elements, both military and non-military, for the preservation and enhancement of the nation's long-term (that is, in wartime and peacetime), best interests." 38

Two implications emerge from this debate. First, while the classicist tradition sees grand strategy as deploying policy at the service of war, the international relations perspective stretches policy rationality to include the coordination of various instruments, ranging from diplomacy to war, economics, and technological innovation. Second, in this more expansive view of grand strategy, war no longer provides the logic that cements its purpose together. This begs the obvious question: what does? This question is, unfortunately, not addressed by Milevski, nor by Brooks and Wohlforth.

Scholars differ on the question of the purpose of grand strategy-and not neatly along paradigmatic lines. Wohlforth, for example, is a renowned realist, but he moves away from a classicist approach that focuses most closely on military security. This conceptual fecundity is a testimony to the vitality of the research being undertaken in this field. But it also signals a lack of common ground. It is no surprise that some skeptics have found the very concept of grand strategy a "useless" exercise for academics 39 and others have claimed it an unhelpful form of "intellectualizing." 40 Even Brands acknowledges that the concept is "subjective" (p. 1, 3), reinforcing the idiosyncratic character of these definitions.

Is this problem avoidable? Conceptual clarification, including definition and meaning, is a basic endeavor of social science. Without agreement, scholars often talk past each other. Some see grand strategy as part of foreign policy, others believe it guides foreign policy. Some consider it a subset of strategy, others consider it as a meta-strategy. Thus, to paraphrase Gray, "right enough" 41 definitions of different aspects of the same phenomenon is one thing; "right enough" definitions of different phenomena, all labeled grand strategy, is another. In this vein, Avery Goldstein argues that "grand strategy may simply not be the sort of phenomenon that calls for a distinct theoretical literature." 42 Although differing in kind and objectives,

\footnotetext{
${ }^{38}$ Kennedy, "Grand Strategy in War and Peace," 5.

${ }^{39}$ Daniel Drezner, "Does Obama Have a Grand Strategy? Why We Need Doctrines in Uncertain Times," Foreign Affairs 90, no. 4 (July/August 2011): 59-61. As it appears, Drezner would prefer "doctrine," another concept that is often confused with strategy and occasionally grand strategy. Brooks and Wohlforth are at loggerheads with Drezner. In fact, they regard doctrines as expressing policies produced by a grand strategy (p. 81).

${ }^{40}$ Marc Trachtenberg, "Making Grand Strategy: The Early Cold War Experience in Retrospect," SAIS Review 19, no. 1 (Winter-Spring1999): 39.

${ }^{41}$ Gray, Strategy Bridge, 17.

${ }^{42}$ Goldstein, Rising Challenge, 18.
} 
propositions, theories, and analytical frameworks, any debate about grand strategy presupposes a shared lexicon and a common way of evaluating the propositions they generate. ${ }^{43}$ Otherwise-in Brands's words-grand strategy remains a "quixotic and pernicious pursuit" (p. 194).

What, then, can be done to resolve this issue? Ideally, we would attempt to do so here. Our substantive point, however, is that establishing consensus on a definition requires collective deliberation and debate as part of a research program. By contrast, the books reviewed are generally more concerned with applying their authors' understanding of grand strategy to the policy agendas of the United States than with reconciling the concept of grand strategy itself. While Milevski effectively describes the evolution of grand strategy in the last two centuries, he devotes relatively little attention to conceptual discussions.

When these works are viewed in combination, this omission raises a key issue. Without a clear idea of what elements are common to its varied conceptions, it is difficult to establish what constitutes an example of an operational grand strategy. As previously mentioned (and discussed more generally below), Brooks and Wohlforth's book provides an example of this fuzziness: it examines both America's superpower status (in the opening three chapters) and American grand strategy (predominantly in the fourth) but is unclear about the relationship between the two. Left unresolved, an abiding issue is whether they are effectively discussing a grand strategy or simply hegemony-whether American primacy is a product of strategy or structure. Nina Silove's response, in a recent article, is to parse out the concept by distinguishing between grand plans, grand principles, and grand behaviors. ${ }^{44}$ While the article addresses an important question, we think her solution raises additional issues. As Silove acknowledges, for example, the line between these three usages is often blurred; for us, the article eludes two major questions. Are plans based on principle? Are both plans and principles woven into patterns of behavior? If the answer to either question is affirmative, then it is difficult to establish distinct lines between the three usages, given that Silove recognizes that the main criterion for drawing a distinction between grand plans and grand principles is the "level of detail" that separates them. ${ }^{45}$

Conceptual clarification will contribute to better social scientific practices, notably promoting scholarly communication and debate. ${ }^{46}$ If proponents of

\footnotetext{
${ }^{43}$ See Baldwin, "Concept of Security," 5-10.

${ }^{44}$ See Nina Silove, "Beyond the Buzzword: The Three Meanings of 'Grand Strategy'," Security Studies 27, no. 1 (2017): 27-57.

${ }^{45}$ Ibid., 44.

${ }^{46}$ On the importance of a "good" concept for the betterment of social sciences, see for instance, John Gerring, "What Makes a Concept Good? A Criterial Framework for Understanding Concept Formation in the Social Sciences," Polity 31, no. 3 (Spring 1999): 357-93; Mark Bevir and Asaf Kedar, "Concept Formation in Political Science: An Anti-Naturalist Critique of Qualitative Methodology," Perspectives on Politics 6, no. 3 (September 2008): 503-517; David Collier and John Gerring, eds., Concepts and Method in Social Science: The Tradition of
} 
restraint employ a formulation of grand strategy that fundamentally differs from advocates of deep engagement, how are we to vet the results of their analyses? We argue that identifying the common elements underlying different uses of grand strategy will test any scholar's ability to disentangle normative from empirical concerns. We do not assume that we can devise a universal definition, but differing definitions facilitate silos rather than shared meaning and legitimate debate. Furthermore, shared understandings may promote a bridge between scholars and policymakers, enabling the latter to rationally examine the relative merits of competing prescriptions. In short, as Felix E. Oppenheim advocated, "the elucidation of the language of political science is ... a most effective way to solve substantive problems of research." ${ }^{47}$

\section{Methodological Issues in the Study of Grand Strategy}

Our second question listed at the outset recalled J. David Singer's formulation that social science is supposed to describe, explain, and predict. But scholars working in positivist traditions rarely venture into the realm of grand strategy. Despite the term's growing popularity, ${ }^{48}$ the number of articles or books that address associated methodological issues is remarkably small. Indeed, the number of doctoral programs where a student or young scholar could be trained on grand strategy, albeit comprising a distinguished group, is even smaller. ${ }^{49}$

Comparing and contrasting the value of the research exemplified in these books is made all the more complicated by the absence of agreed norms of evidence, discussions of appropriate methods, and agreement as to what constitutes an appropriate case-or even the relevant universe of cases. Just one example is the issue of who can formulate and implement a grand strategy. As

Giovanni Sartori (New York and London: Routledge, 2009); Andrew C. Gould, "Conflicting Imperatives and Concept Formation," Review of Politics 61, no. 3 (Summer 1999): 439-63.

${ }^{47}$ Felix E. Oppenheim, "The Language of Political Inquiry: Problems of Clarification," in Handbook of Political Science, Volume 1-Political Science: Scope and Theory, ed. Fred I. Greenstein and Nelson W. Polsby (Reading, MA: Addison-Wesley, 1975), 284.

${ }^{48}$ For an (albeit crude) measure of its growing popularity, see Alex Roland, "Article Review 93 on 'Beyond the Buzzword: The Three Meanings of Grand Strategy'," International Security Studies Forum, accessed 21 February 2018, https://issforum.org/articlereviews/93-grand-strategy.

${ }^{49}$ For example, see Yale University's Brady-Young Program at http://grandstrategy.yale.edu/ and the Duke American Grand Strategy Program at https://sites.duke.edu/agsp/. Examining the websites of both programs does not clarify whether either focuses on methodological issues. On the articulation and implementation of grand strategy see Martel, Grand Strategy, 89-90 and 47-56 respectively, but also as a theme throughout the volume. The Strategy and Policy Department of the Naval War College, which styles itself as one of the premier institutions teaching about grand strategy, does not focus on methodological issues but rather on teaching a series of cases. Its annual Workshop on the Teaching of Grand Strategy brings together Naval War College professors and faculty from leading civilian institutions in the belief that "the education that you deliver and the writings that you produce stand as an answer to those who lament the dearth of strategic thinking in today's world. We can learn from each other about the craft of teaching courses on strategy and what best practices to follow in preparing our students for the leadership roles and the challenges before them in the years ahead." Accessed 18 August 2017, https://www.usnwc.edu/About/News/August-2012/ Strategy-and-Policy-Department-Workshop-on-the-Tea.aspx. 
Milevski notes, scholars like Paul Kennedy argue that grand strategy "concerned great rather than small or medium powers" and "thus is not a universal function or consideration of strategic theory or practice." 50 Yet why should this be true? If, as discussed earlier in this review, both classicist and IR versions of grand strategy are concerned with how a state provides for its national security and/or foreign policy, why shouldn't states of any size formulate and implement a grand strategy? The grand strategies of smaller states might not have the "worldmaking" ambitions and implications of US grand strategy after World War II or of the United Kingdom at the height of Pax Britannica. But they might help explain how each copes with security issues in its own neighborhood and place within the global economy. ${ }^{51}$

Essentially, there are three basic methodological questions raised by these books: 1) What is a case in the study of grand strategy?; 2) Is the purpose of scholarship explanation or prescription?; and 3) Should scholars who work in this field study history (purely as descriptive narrative) or test theories (which may also involve the study of history)? It is to these questions that we now turn.

\section{What is a Case of Grand Strategy?}

Description often involves the study of cases. Grand strategy research seems tailor made for case study analysis-especially process tracing, which entails "the systematic examination of diagnostic evidence selected and analyzed in light of research questions and hypotheses posed by the investigator." 52 But relatively few scholars of grand strategy explicitly use such methods, although Christopher Layne has deployed process tracing effectively. ${ }^{53}$ Others examine multiple cases but more often focus on issues that are subcomponent parts of, are orthogonally related to, or intersect with grand strategy, rather than grand strategy itself. ${ }^{54}$

Indeed, the very definition of a case is contested. Studies alternatively treat a grand strategic archetype (such as containment) as a case, the

\footnotetext{
${ }^{50}$ Milevski (p. 120), following Kennedy, "Grand Strategies in War and Peace: Toward a Broader Definition," in Grand Strategies in War and Peace.

${ }^{51}$ According to Milne, a number of American strategic thinkers, especially those trained in the social sciences (notably Woodrow Wilson, Paul Nitze, and Paul Wolfowitz), view the international system as "makable [sic] following the identification and application of appropriate patterns and theories." David Milne, Worldmaking: The Art and Science of American Diplomacy (New York: Farrar, Straus and Giroux, 2015), 16.

${ }^{52}$ David Collier, "Understanding Process Tracing," PS: Political Science and Politics 44, no. 4 (October 2011): 823.

${ }^{53}$ Christopher Layne, The Peace of Illusions: American Grand Strategy from 1940 to the Present (Ithaca: Cornell University Press, 2006), 11-12.

${ }^{54} \mathrm{An}$ important example of this is Michael Beckley's work on entrapment. But while Beckley's study has important implications, it looks at a dynamic intrinsic to grand strategy, not the values, ways, means, and ends of grand strategy. See Michael Beckley, "The Myth of Entangling Alliances: Reassessing the Security Risks of U.S. Defense Pacts," International Security 39, no. 4 (Spring 2015): 7-48.
} 
historical grand strategy of an individual nation-state as a case (such as the United States, Great Britain, Russia, or China), ${ }^{55}$ and grand strategies pursued by several individual nation-states during a specific era (such as the Interwar Period) as a case. ${ }^{56}$ Yet even narrower studies that focus on the grand strategies of specific states generate confusion. Within the literature focusing on the United States, for example, scholars have defined a presidential administration (such as Eisenhower's), an era (the post-Cold War), ${ }^{57}$ or some period demarcated by a specific beginning (the end of World War II) or an end (the end of the Cold War) as a case.

Of the volumes we review, Hal Brands's work best illustrates this problem. Brands implicitly assumes that individual American presidential administrations constitute a logical case. Thus, in exploring post-World War II American grand strategy, he elects to focus on the administrations of four presidents-Truman, Nixon, Reagan, and George W. Bush-in comparing their strategies as four distinct cases. This approach would make sense if the United States changed its grand strategy whenever presidential administrations change. Yet other scholars (notably among whom is Posen) have suggested that grand strategies generally endure, changing only with geopolitical circumstances or major domestic disturbances. James Kurth even adapts a version of the long cycles of history to analyze American grand strategy; in essence, he argues that a nation changes its grand strategy upon winning decisive conflicts. ${ }^{58}$ Thus, for example, the grand strategy of containment arose with the post-war emergence of the Soviet Union as a nuclear armed superpower competitor, initiating the bipolar international system. ${ }^{59}$ Containment remained America's grand strategy until the collapse of the Soviet Union and its Warsaw Pact. Consistent with this view, the conclusion of the Cold War stimulated a raft of articles advocating possible successor strategies to containment. ${ }^{60}$ At first

\footnotetext{
${ }^{55}$ While the concept of case used to generate strong discussions (for or against) within the discipline of history, there are increasing calls to adopt the conventional standards of the philosophy of social sciences, including a more rigorous treatment of case studies. For an example, see Tillman Sauer and Raphael Scholl, eds., The Philosophy of Historical Case Studies (Berlin: Springer, 2016).

${ }^{56}$ Jeffrey W. Taliaferro, Norrin M. Ripsman, and Steven E. Lobell, eds., The Challenge of Grand Strategy: The Great Powers and the Broken Balance Between the World Wars (Cambridge: Cambridge University Press, 2013).

${ }^{57}$ Aaron L. Friedberg, In the Shadow of the Garrison State: America's Anti-Statism and Its Cold War Grand Strategy (Princeton: Princeton University Press, 2000).

${ }^{58}$ James Kurth, "America's Grand Strategy: A Pattern of History," The National Interest, no. 43 (Spring 1996): 3-19.

${ }^{59}$ See the opening sentences of Steve Walt's 1989 article in International Security: "Since the Second World War the main objective of U.S. grand strategy has been to prevent the territorial expansion by the Soviet Union while avoiding a major war." Stephen M. Walt, "The Case for Finite Containment: Analyzing U.S. Grand Strategy," International Security 14, no. 1 (Summer 1989): 5-49.

${ }^{60}$ As examples, see Stephen Van Evera, "Why Europe Matters, Why the Third World Doesn't: American Grand Strategy after the Cold War," Journal of Strategic Studies 13, no. 2 (1990): 1-51; Robert J. Art, "A Defensible Defense: America's Grand Strategy after the Cold War," International Security 15, no. 4 (Spring 1991): 5-53;
} 
glance, Milevski's volume appears to implicitly endorse this position by devoting its penultimate chapter to "Post-Cold War Grand Strategic Thought"; a closer reading reveals, however, that the division between Cold War and post-Cold War grand strategic thought is largely a function of the Cold War's impact on the scholarly and government communities. The Cold War stand-off placed a premium on studying "nuclear strategy and limited war theory" (p. 106).

Confusion over what constitutes a case matters in this context for two reasons. First, absent agreement on how a case is defined, possibilities for the culmination of conceptual knowledge are limited: scholars often talk past each other because they are not debating the same phenomena. Second, little progress can be made toward understanding the more nuanced points of systemic analysis. For example, what drives strategic change or adjustment? How do we know when (and under what conditions) a grand strategy changes? Who is responsible for their formulation? Do heroic individual strategists (like George Kennan) develop grand strategies, or does it fall to what Williamson Murray refers to as "corporate bodies?"61

These questions remain unresolved in the four books we examine. Brands, the historian, studies presidential administrations; Brooks and Wohlforth consider aggregate data as they explore the American case visà-vis the international system and potential rivals, notably China; Posen examines how the United States came to dominate the global security system (Command of the Commons) and how this predominance might be maintained in the face of changing geopolitical conditions; and Milevski reviews the concept of grand strategy itself rather than focusing on examples of it. To the extent that they study cases, they primarily examine one country-the United States. ${ }^{62}$ They do so, in the words of Brands, because the postwar world is "the era in which U.S. foreign policy becomes fully and consistently global in scope, and in which the foreign policy, defense, and intelligence bureaucracies began to take on something approximating their current size and form" (p. 15). The evident dominance of the grand

\footnotetext{
Michael Mastanduno, "Preserving the Unipolar Moment: Realist Theories and U.S. Grand Strategy after the Cold War," International Security 21, no. 4 (Spring 1997): 49-88. Naturally, when the unipolar moment waned after less than a decade, enterprising scholars proposed another grand strategy and a new language for analyzing America's strategic choices. Christopher Layne, "From Preponderance to Offshore Balancing: America's Future Grand Strategy," International Security 22, no. 1 (Summer 1997): 86-124.

${ }^{61}$ Williamson Murray, "Introduction," in Successful Strategies: Triumphing in War and Peace from Antiquity to the Present, ed. Williamson Murray and Richard Hart Sinnreich (Cambridge: Cambridge University Press, 2014$), 2$.

${ }^{62}$ Even authors who include other countries often do so from a US perspective. In Michael Beckley's excellent article, "The Myth of Entangling Alliances," for example, he tested the main claim against entanglement: the risk of America being drawn into a war due to an alliance commitment. He examined 188 disputes but found no conclusive evidence of entanglement. Yet Beckley's analysis remains centered upon the United States. It does not compare America's grand strategy vis-à-vis those of other nations. Instead, Beckley studies US behavior across several disputes to determine the factors that prompted its actions. See Beckley, "Myth of Entangling Alliances."
} 
strategy literature by Americans writing about American cases (as demonstrated by three of these four books) might be yet another example of Susan Strange's famous observation: “This special form of nonterritorial imperialism is something that many American academics, brought up as liberals and internationalists, find it hard to recognize."63

This US-centric focus has not always been the case. As Milevski chronicles, many early proponents of the idea of grand strategy were British and French. ${ }^{64}$ The fact that both countries were, for an extended period, the dominant global power suggests a strong connection between imperial projects and thoughts about grand strategy. It also suggests that the dominance of the American case will wane if America's relative power declines. Scholars of the political Left are quick to point out the relationship between US hegemony (the Imperium) and those who study American foreign and security policy. ${ }^{65}$ But none of these factors point to which country scholars might predominantly study in the decades ahead.

Regardless, the reliance on a single case-one that is not in the sense denoted by Harry Eckstein as critical-limits the capacity for generalizability or comparison. ${ }^{66}$ Nor does the oft-made claim that grand strategy is the province of a few great powers address a major problem: the varied ways in which the United States is studied leaves little capacity to compare cross-nationally. As a result, for the bulk of contemporary scholars of grand strategy, its study is synonymous with the exclusive study of the United States. This conflation of grand strategy as American grand strategy, sui generis, leaves it open to criticism as arrogant, parochial, nongeneralizable, and (ironically) irrelevant beyond the Washington beltway.

\section{Is Grand Strategy about Explanation or Prescription?}

The second of Singer's components is explanation, the establishment of cause-and-effect relationships. But this task remains elusive in the literature. Many scholars writing on grand strategy express a deep dissatisfaction with their nation's current strategies and policies. Historians and historically-minded social scientists ${ }^{67}$ share a similar dissatisfaction (or perhaps puzzlement) - not with current policies, but with the behavior of states that led to catastrophic wars. ${ }^{68}$ As one noted scholar pointed out to us, those writing about grand strategy often rely on underlying causative

\footnotetext{
${ }^{63}$ Susan Strange, "Cave! Hic Dragones: A Critique of Regime Analysis," International Organization 36, no. 2 (Spring 1982): 482.

${ }^{64}$ Milevski, p. 15-16 on the French and p. 45-60 on the British.

${ }^{65}$ Perry Anderson, American Foreign Policy and Its Thinkers (Brooklyn: Verso, 2015).

${ }^{66}$ Harry Eckstein, "Case Study and Theory in Political Science," in Handbook of Political Science, vol. 7, ed. Fred I. Greenstein and Nelson Polsby (Reading, MA: Addison-Wesley, 1975), 96-123.

${ }^{67}$ Although not concerned solely or even primarily with grand strategy, some volumes share a concern with both current strategic issues and the mistakes of the past. See, for example, Richard N. Rosecrance and Steven E. Miller, eds., The Next Great War? The Roots of World War I and the Risk of U.S.-China Conflict (Cambridge, MA: MIT Press, 2014).

${ }^{68}$ See the literature on German Grand Strategy before and during the two World Wars: for example, Dennis Showalter, "Total War for Limited Objectives: An Interpretation of German Grand Strategy," in Grand Strategy in War and Peace.
} 
relationships when advocating a particular course of action. But if this is so, these causative relationships are implicit, buried in the bowels of an argument rather than transparent and subject to formal evaluation. Consequently, prescription often usurps causation as their major goal. Milevski recognizes this trend in the 1990s and 2000s and attributes it to "uncertainty over what the purpose of United States foreign policy should be" following the success of containment and the collapse of the Soviet Union (p. 129-30). ${ }^{69}$

As suggested earlier, Posen's Restraint clearly falls into this category of emphasizing prescription over explanation. Posen argues that the continued pursuit of liberal hegemony, particularly since the "unipolar moment" in the immediate aftermath of the end of the Cold War, "will likely prove not merely costly and counterproductive, as it has been in the recent past, but disastrous" (p. 165). The core of his very sophisticated analysis rests on four pillars: as it pursues liberal hegemony, those who suffer during periods of social, political, and economic change blame the United States for their woes and balance against it; nationalism remains a potent force against American designed and led international institutions; the capacity for organized violence diffuses still further; and free riders benefit from American largesse while reckless drivers threaten to drag it into unwarranted conflicts (p. 165-66). In response, Posen prescribes a strategy of restraint to reduce costs and avoid entrapments, yet continue to sustain American control of the commons.

Brooks and Wohlforth aver a commitment to a "scholarly" approach that rests on "sound social science" (p. 10). But they comparably proclaim that in their "most comprehensive assessment of US grand strategy's grounding in theory and evidence yet attempted, we demonstrate that a foundational policy pillar-a globally engaged America-remains the wisest choice" (p. 11-12). Rather than explain why American policymakers chose deep engagement, Brooks and Wohlforth often seem more interested in justifying why they should continue to do so in future.

This tendency toward prescription is unexceptional and has endured as the dominant mode of discourse on grand strategy for a long time. Of the "grand strategists" discussed in one study, several were journalists like Walter Lippman or unaffiliated public intellectuals like Charles Beard. ${ }^{70}$ More recently, Charles Krauthammer wrote one of the most cited pieces on US grand strategy in the post-Cold War era. He concluded, "We are in for abnormal times. Our best hope for safety in such times, as in difficult times past, is in American strength and will-the strength and will to lead a unipolar world, unashamedly laying down the rules of world order and being prepared to enforce them."71

\footnotetext{
${ }^{69}$ Moreover, debate focuses on Posen and Ross's description of the four major contending grand strategic prescriptions - neo-isolationism, selective engagement, cooperative security, and primacy - that helped shaped much of the later grand strategy literature. Posen and Ross, "Competing Visions."

${ }^{70}$ David Milne, Worldmaking.

${ }^{71}$ Charles Krauthammer, "The Unipolar Moment," Foreign Affairs 70, no. 1 (Winter 1990/1991): 23-33. See also his slightly less influential follow up, Charles Krauthammer, "The Unipolar Moment Revisited," The National Interest, no. 70 (Winter 2002/03): 5-18.
} 
Pointedly, Posen is deeply conversant with the policy challenges facing American political and military leaders in the current security environment. Likewise, Colin Dueck set out to define and assess the grand strategy of the Obama administration. Drawing on the relevant literature, Dueck concluded that President Obama "simply pursued an implicit overall strategy of American retrenchment and accommodation, in order to focus on domestic policy legacies, and in the hope that this approach would somehow encourage more peaceful cooperative relations overseas. The strategy was poorly executed and characterized by yawning gaps between words and actions in one case after another. Internationally it hasn't worked." ${ }^{\text {"2 }}$ Not surprisingly, Dueck's remedial prescriptions follow.

The same cannot be said for other recent books that take an overtly normative or prescriptive position on US grand strategy. One example is journalist Bret Stephen's screed, both a polemic against the policies of the Obama administration and an ahistorical, atheoretical set of prescriptions for what ails the United States. ${ }^{73}$

Prescription may remain a central element of grand strategy. Additionally, each formulation inherently embodies an alleged causal chain between behavior and results. Policy makers choose remedies from among alternative choices that they think best respond to the many challenges they face. But prescriptions are only robust to the extent that they are able to tell policymakers what conditions are required in order to achieve a given outcome. They should be able to answer the question: under what conditions can this specific form of grand strategy be implemented?

Despite its potential worth, a prescriptive approach is not without problems. To start with, it portrays any grand strategy as including an orienting principle that anchors all policy options. ${ }^{74}$ To succeed, policymakers must remain tightly within the coordinates set by the grand strategic prescription. However, different-indeed contrasting-principles often coexist at any particular moment within a polity, such as the need to maximize both security and liberty. Also, because prescriptions express normative commitments, they tend to be less adaptive.

Instead of a normative account of what states should do to attain a particular goal, more work is needed that explains the conditions under which that goal is feasible, including evidence about why prescribed action will lead to a specific outcome. For example, what will allow a grand strategy to take root or be successful, and what will its consequences be, based on evidence drawn from varied cases?

\footnotetext{
${ }^{72}$ Colin Dueck, The Obama Doctrine: American Grand Strategy Today (Oxford: Oxford University Press, 2015), 256.

${ }^{73}$ Bret Stephens, America in Retreat: The New Isolationism and the Coming Global Disorder (New York: Sentinel, 2015).

${ }^{74}$ Even books such as Brands's, which do not press for a definite course of action, hanker for prescriptive "guidelines for thinking about (grand strategy) and the dilemmas it entails" (p. 194). Moreover, in a later work, Brands discusses different options - that is, possible normative choices-for American grand strategy. See Hal Brands, American Grand Strategy and the Liberal Order: Continuity, Change, and Options for the Future (Santa Monica: RAND Corporation, 2016).
} 
Furthermore, a study emphasizing prescription needs to demonstrate how changes in the international environment alter states' preferences and behaviors in a way consistent with their preferred grand strategy. Scholars' preferences for one approach often endure even as the challenges change. Posen recognizes this problem when he notes that, "Although the outlines are not clear, advocates of alternative US grand strategies during the last decade now seem inclined to superimpose these strategies on the campaign against terror." 75 The upshot of this argument is that when scholars advocate a grand strategy, they tend to cling to its core assumptions even when discordant evidence arises. ${ }^{76}$ Thus, instead of treating explanation as a second-order venture that supports a normative point established a priori, scholars should treat it as the engine from which policies are derived.

Finally, policy prescriptions often reflect the theoretical commitments of the scholars who defend them. As a consequence, notes Milevski, "neoconservatives propose one grand strategy, the liberals another, the realists a third, and so on" (p. 129). From this perspective, scholars need to elucidate whether this way of proceeding does not prioritize the logic of justification at the expense of the logic of explanation.

\section{Should Grand Strategy Focus on the Descriptive Study of History or Theory Testing?}

Perhaps the most accessible research on grand strategy comes from the tradition of narrative history or social scientists using a largely historical approach. The study of history seems almost written into the DNA of the field. In fact, the erstwhile founder of American grand strategy, Alfred Thayer Mahan, left his modest career as a naval officer with the publication of The Influence of Seapower on History, 1660-1793, a narrative account of Great Britain's rise to naval mastery and thus global preeminence in the nineteenth century. ${ }^{77}$ Milevksi's volume both confirms and offers a counterpoint to this trend (p. 30-37). It owes more to the disciplines of the history of ideas or even intellectual history, ${ }^{78}$ carefully tracing "the actual evolution of grand

\footnotetext{
${ }^{75}$ Barry R. Posen, "The Struggle Against Terrorism: Grand Strategy, Strategy, and Tactics," International Security 26, no. 3 (Winter 2001-2002): 53.

${ }^{76}$ Lakatos criticizes this as inconsistent with sophisticated methodological falsification. See Lakatos, "Falsification," 109, 116-22.

${ }^{77}$ David Milne's chapter on Mahan frames Mahan's influence, juxtaposing his personal development, books, articles, and public profile with the views of his critics (including President Woodrow Wilson) and supporters (including President Theodore Roosevelt). Milne, Worldmaking, 22-69. For a deeper assessment, see Jon Tetsuro Sumida, Inventing Grand Strategy and Teaching Command: The Classic Works of Alfred Thayer Mahan Reconsidered (Baltimore: Johns Hopkins University Press, 1999).

${ }^{78}$ See Peter E. Gordon, "What Is Intellectual History? A Frankly Partisan Introduction to a Frequently Misunderstood Field," (unpublished manuscript, Harvard University, Boston, MA, 2012), accessed 23 March 2017, https://sydney.edu.au/intellectual-history/documents/gordon-intellectual-history.pdf. Gordon defines and contrasts the history of ideas vice intellectual history: "Broadly speaking, intellectual history is the study of intellectuals, ideas, and intellectual patterns over time" versus "Intellectual history resists the Platonist expectation that an idea can be defined in the absence of the world, and it tends instead to regard ideas as historically conditioned features of the world which are best understood within some larger context." Gordon, "What Is Intellectual History?," 1-2.
} 
strategic thought, and the complexity and variety of views, definitions and interpretations therein" (p. 5).

We are advocates-not critics-of historical methods, and we have and do employ them in the study of international relations. But how it is done is key, particularly with regard to whether it allows for theory testing. One approach is an assessment that allows for an examination of alternative explanations. Another is a historical narrative that eschews such exploration.

With the partial exception of Wohlforth and Brooks's presentation of raw data, none of the scholars and books under review here make much use of traditional social science scholarship, whether in the form of quantitative analysis or application of rigorous comparative case study methodology. While Wohlforth and Brooks utilize a rich and extensive range of data, they do not conduct direct empirical work per se, and the data they do examine is explicitly utilized for the purpose of defending their preferred grand strategy. In other words, there is considerable difference among the authors with regards to what counts as evidence. This is illustrated by Brands's and Posen's books. The depth of Brands's impressive study of American postwar history contrasts with Posen's vast knowledge of military operations, but neither tests hypotheses to assess differing explanations in even a loosely (or soft) positivistic framework. A question thus emerges: is this a blessing that has allowed a rich interdisciplinary approach or a shortcoming in that the conceptual and theoretical strengths of social science have not been brought to bear in the study of grand strategy? Presumably there is room for both, but at the moment the bias is evident.

\section{Toward a Mature Research Program for Grand Strategy}

Matters of definition, causation, and evidence generate the inevitable question: what needs to be done to develop a mature research program for grand strategy? At this point, we too become prescriptive in that we believe that parsing and reparsing familiar cases is not a tactic for interesting and readable, much less progressive, scholarship. To reinforce our prior comments, we are not opposed to the current strains of scholarship and strongly concur that there is a place for historical analysis, intellectual history, and use of American-dominated case studies. Yet these components collectively cannot form the entire contours of analysis. We believe that to be consistent with the requirements of a research program will require a greater focus on four points.

First, scholars should use a greater variety of methods-possibly including mixed methods. Perhaps the most notable recent example that may serve as a model is represented by Dale Copeland's Economic Interdependence and 
War, winner of the International Studies Association's Best Book Award, which combines qualitative and quantitative analysis in the evaluation of alternative explanations. ${ }^{79}$ Other subfields of international relations demonstrate this methodological pluralism with a great commitment to both theory building and testing. The study of substate war and ethnic conflict provides an excellent example of a maturing research program. Journals largely dedicated to varying methodological approaches proliferate and scholarship in the field flourishes. ${ }^{80}$ This variation has facilitated the evolution of a diversity of approaches, many of which provide transparent ways to assess the utility of the evidence presented. According to Milevski, by contrast, scholars in the field of grand strategy are too prone to look for "appropriate historical evidence" to corroborate their assumptions (p. 151).

Second, scholars should adopt an explicitly comparative agenda, whether across countries or time. We reject the view that the study of grand strategy only applies to study of the United States, sui generis, or even only great powers. Rather, a greater focus should be placed on developing frameworks that extend beyond the few obvious candidates, such as China and Russia. Small states may not be explicitly comparable to large ones (in respecting the contours of most-similar research designs). But the assumption that small states can't formulate or implement grand strategies seems questionable, even upon only superficial examination of countries as diverse as Saudi Arabia, Iran, and Norway. In each case, they configure elements of power in starkly different ways with clear (albeit again starkly different) goals in mind. ${ }^{81}$

Our third suggestion is that scholars unpack-in a systematic fashionthe relationship between ends, ways, and means and between grand strategy and military strategy, politics, and policy. Both scholars and policymakers assume there is an organic relationship between the formulation of a grand strategy and its implementation. Yet they generally critique the inadequacy of implementation efforts - a point that Brands admirably demonstrates in his review of the efforts of successive administrations. At the heart of every proposed variant of grand strategy is a logic about how values relate to goals and processes in a causative manner. But these elements are not organic and are significantly underexplored in the literature.

This leads to our fourth and final point: that scholarship should explicitly focus on causality rather than prescription. Prescriptions may indeed imply

\footnotetext{
${ }^{79}$ Dale C. Copeland, Economic Interdependence and War (Princeton: Princeton University Press, 2015).

${ }^{80}$ The list is long, but among the more auspicious are International Security, Journal of Conflict Resolution, Journal of Peace Studies, and World Politics.

${ }^{81}$ One recent example that includes states not generally categorized as great powers is William I. Hitchcock, Melvin P. Leffler, and Jeffrey W. Legro, eds., Shaper Nations: Strategies for a Changing World (Cambridge, MA: Harvard University Press, 2016). In a modest effort to further address this problem, we are currently coordinating a ten-country study on comparative grand strategy, with an edited volume (Oxford University Press, under contract) on its empirical aspects and Balzacq and Reich are working on an authored volume on its theoretical and policy dimensions.
} 
causal relations. But making them explicit enhances the prospect of building consensus about key definitions, what constitutes relevant evidence, and the most important variables in the construction (or consequence) of any grand strategy. Lessons gleaned from basic research and then applied to policy-what Alexander George and Richard Smoke over four decades ago described as a diagnostic approach-differs from prescription. ${ }^{82}$ The former (research utilization through a knowledge-driven model) is a twostage process. The latter skirts that issue by directly linking evidence to prescription and, as we have demonstrated, this generates many problems. ${ }^{83}$

We find that these issues remain unaddressed in the field of grand strategy, reducing its capacity for analytic rigor. Any robust research program requires a minimal consensus about what is being studied, how to study it, and what counts as appropriate evidence. We have used these four books to assess the state of the research program. As "friends of the court," we conclude that they are all excellent books. It is in that spirit that we offer constructive suggestions for how to move forward.

\section{Acknowledgments}

The authors wish to thank Jonathan Caverley and Bob Art for detailed comments, Rachael Shaffer for editorial assistance, and the anonymous reviewers at Security Studies. Thierry Balzacq acknowledges the remarkable support of the Asia-Pacific College of Diplomacy at the Australian National University, the Francqui Foundation and the Namur Advanced Research College (NARC). Simon Reich also wishes to thank his hosts at IRSEM in Paris and the Gerda Henkel Foundation for its generous support.

\footnotetext{
${ }^{82}$ Alexander George and Richard Smoke, Deterrence in American Foreign Policy: Theory and Practice (New York: Columbia University Press, 1974), 636.

${ }^{83}$ For a discussion of that issue, see Carol H. Weiss, "The Many Meanings of Research Utilization," Public Administration Review 39, no. 5 (September-October 1979): 426-31.
} 